\section{Reproductive outcome in carrier couples of $\beta$-thalassemia disorders in a tertiary hospital in central India}

\author{
Ranbir S. Balgir \\ Department of Biochemistry, Regional \\ Medical Research Centre for Tribals \\ (Indian Council of Medical Research), \\ Jabalpur, Madhya Pradesh, India
}

\begin{abstract}
The $\beta$-thalassemia syndromes and hemoglobin disorders are the major genetic and public health challenges in Central India. In view of dubious credit of the highest infant mortality rate in Madhya Pradesh (62 as against 47 per 1000 livebirths of India in 2011) it was presumed that carrier couples of $\beta$-thalassemia disorders might be one of the contributing factors to high mortality. A total of 280 couples including their offspring with at least one affected and/or suspected case of $\beta$ thalassemia/sickle cell disorders referred to our Centre from a tertiary hospital, Jabalpur during March 2010 to February 2013 were consecutively studied as matched case controls. Out of $280 \mathrm{cou}-$ ples, 200 were found normal and 80 couples had different $\beta$-thalassemia disorders. $\beta$-thalassemia carrier couples had significantly higher relative fertility (mean number of conceptions, i.e. 2.457 versus 1.480$)$, higher infant mortality ( $3.5 \%$ versus $1.3 \%)$, higher below 10 years mortality $(7.0 \%$ versus $2.7 \%$ ) and lower surviving offspring (925.9 versus 970.6) than of controls. Still-births were three times lower (12.3), neonatal deaths almost two folds higher (24.7), three folds higher infant mortality (37.0) and almost three times higher below 10 years mortality per 1000 live-births were observed in carriers of $\beta$-thalassemia major than in controls. The present study indicated that afflicted couples of these hereditary disorders are increasing the afflicted offspring, being $60.7 \%$ surviving against controls (39.3\%). This increased production of afflicted (heterozygous and homozygous) offspring leads to increased morbidity and mortality and might be contributing towards increased neonata//infant mortality in Madhya Pradesh of Central India. As a preventive measure, affected families were imparted genetic/marriage counseling.
\end{abstract}

\section{Introduction}

The $\beta$-thalassemia disorders are a group of hereditary blood disorders, characterized by anomalies of the synthesis of $\beta$-chains of hemoglobin $(\mathrm{Hb})$, resulting in variable phenotypes ranging from severe anemia to clinically asymptomatic individuals. ${ }^{1-4}$ These disorders have a wide geographical spread throughout the country, the highest prevalence being in the Northwestern, followed by North-eastern, and the lowest being in Southern parts of India. ${ }^{5}$ The $\beta$ thalassemia disorders are caused by point mutations or, more rarely, deletions in the $\beta$ globin gene on chromosome 11 , leading to reduced $\left(\beta^{+}\right)$or absent $\left(\beta^{0}\right)$ synthesis of the $\beta$ chains of hemoglobin. ${ }^{6}$ Transmission is autosomal recessive. Individuals of thalassemia major (homozygous $\beta$-thalassemia) usually present a spectrum of clinical manifestations (signs and symptoms) within the first two years of life with severe anemia, requiring regular red blood corpuscle (RBC) transfusions.

Untreated or poorly transfused individuals of thalassemia major are seen in some developing countries with growth retardation, pallor, jaundice, poor musculature, hepatosplenomegaly, leg ulcers, development of masses from extra-medullary hematopoiesis, and skeletal changes that result from expansion of the bone marrow. ${ }^{4}$ In persons of homozygous $\beta$-thalassemia, low levels of hemoglobin lead to lack of oxygen in many parts of the body. Affected individuals especially the children develop life-threatening anemia or shortage of red blood cells, which can cause pale skin, weakness, fatigue, and more serious complications. ${ }^{6}$ Persons of homozygous $\beta$-thalassemia are at an increased risk of developing abnormal blood clots. They do not gain weight and grow at an expected rate (failure to thrive) and may develop yellowing of the skin and whites of the eyes (jaundice). Affected individuals may have an enlarged spleen, liver, and heart, and their bones are misshapen. ${ }^{6} \mathrm{~A}$ few adolescents of thalassemia major experience delayed puberty. Many people of homozygous $\beta$-thalassemia, except thalassemia intermedia, have such severe symptoms that they need frequent blood transfusions to replenish their RBC supply. Regular transfusion therapy in homozygous thalassemia leads to iron overloadrelated complications including endocrine (hormonal) complications (growth retardation, failure of sexual maturation, diabetes mellitus, and insufficiency of the parathyroid, thyroid, pituitary, and less commonly, adrenal glands), dilated myocardiopathy, liver fibrosis and cirrhosis. ${ }^{6}$

Diagnosis of thalassemia is based on hematological, biochemical and/or molecular genetics testing. ${ }^{7}$ Hematological indices of RBC show microcytic anemia. Homozygous thalassemia is characterized by reduced $\mathrm{Hb}$ level $(<7 \mathrm{~g} / \mathrm{dL}$ ), mean corpuscular volume (MCV) $>50<70 \mathrm{fL}$ and mean corpuscular $\mathrm{Hb}(\mathrm{MCH})$ $>12<20 \mathrm{pg}$. Thalassemia minor (trait) is characterized by reduced MCV and MCH, with
Correspondence: Ranbir S. Balgir, Department of Biochemistry, Regional Medical Research Centre for Tribals (Indian Council of Medical Research), Nagpur Road, P. 0: Garha, Jabalpur-482 003, Madhya Pradesh, India.

E-mail: balgirrs@yahoo.co.in

Key words: carrier couples, $\beta$-thalassemia major, sickle cell disorders, high fertility, neonatal mortality, infant mortality, reproductive wastage.

Acknowledgements: the author is grateful to Dr. V. M. Katoch, Secretary, Department of Health Research, Government of India, and Director General, Indian Council of Medical Research, New Delhi for the permission and providing the necessary research facilities. Author gratefully acknowledges Dr. Shashi Khare, and Dr. Sharad Jain of NSCB Medical College \& Hospital, Jabalpur for referring the patients for investigations. Technical help of Mr. V. K. Kachhi and Mr. P. Patel, Laboratory Technicians is thankfully acknowledged. Thanks are due to all the couples for their kind cooperation during the study.

Funding: Intra-mural, Regional Medical Research Centre for Tribals (ICMR) Jabalpur, India.

Conflict of interests: the author declares no potential conflict of interests.

Received for publication: 3 September 2013. Revision received: 15 February 2014.

Accepted for publication: 20 May 2014.

This work is licensed under a Creative Commons Attribution 3.0 License (by-nc 3.0).

\section{(C) Copyright R.S. Balgir, 2014}

Licensee PAGEPress, Italy

Thalassemia Reports 2014; 4:1907

doi:10.4081/thal.2014.1907

increased hemoglobin $\mathrm{A}_{2}$ level. ${ }^{6}$ Peripheral blood smear in affected individuals show morphological changes in RBC such as microcytosis, hypochromia, anisocytosis, poikilocytosis (spiculated tear-drop and elongated cells), and nucleated RBC (i.e., erythroblasts). The number of erythroblasts is related to the degree of anemia, and markedly increases after splenectomy. ${ }^{6}$ Genetically susceptible individuals to thalassemia include: infants, growing children, adolescents, and a large number of ignorant people. Sometimes, inadequate availability of oxygen to fetus may also lead to abortion, miscarriage or stillbirth. Inherited hemoglobin disorders are responsible for high infant morbidity, mortality and fetal wastage due to no or minimal treatment in India. ${ }^{8,9}$

The primary purpose of screening is the identification of infants with $\beta$-thalassemia for whom early intervention has shown markedly reduced morbidity and mortality. ${ }^{10}$ Inherited hemoglobin disorders are expected to contribute to infant mortality and childhood 
mortality if left untreated. Unfortunately, in the state of Madhya Pradesh, there is a dearth of physicians specializing in the clinical management and treatment of blood disorders including the sickle cell disease and $\beta$-thalassemia syndromes.

A great deal of literature is available regarding the clinical and hematological aspects of these disorders, but the details regarding the reproductive outcome in affected couples are scanty in India. In view of credit for the highest infant mortality rate in the state of Madhya Pradesh (62 per thousand live-births in 2011) in comparison to other states and the average of 47 for India; and the high prevalence of hemoglobin disorders in the State ${ }^{11,12}$ it was presumed that $\beta$-thalassemia disorders might be one of the significantly contributing factors for infant/neonatal mortality in carrier couples in Madhya Pradesh, India.

\section{Material and Methods}

A total of 280 couples including their offspring with at least 1 suspected/confirmed case of anemia/hemoglobinopathies routinely referred by the experts (in Gynaecology, Pediatrics, and Blood Bank) for investigations/confirmation of diagnosis, attending Netaji Subhash Chandra Bose Medical College \& Hospital, Jabalpur, Madhya Pradesh in Central India were included in the study. The ethical clearance was obtained from the Human Ethical Committee of Regional Medical Research Centre for Tribals (ICMR), Jabalpur.

Confirmed cases of $\beta$-thalassemia/sickle cell disorders formed our study group and the negatives, free of hematological disorders/anemia, after rigorous scrutiny, were taken as control group. The cases, suffering from other hemoglobinopathies and/or hematological disorders, and genetic abnormalities were excluded from the study. Those cases with iron deficiency anemia, malaria, accidental or induced abortion, were also excluded from the study. All the non-genetic confounding factors more or less were similar for both groups (matched case controls), being taken from the same population source. Detailed reproductive history of each couple was recorded retrospectively like total number of conceptions, abortions, miscarriages or still-births, live-births, surviving children, neonatal or infant deaths, etc.

In this study, genotypes of couples such as AA/AA stands for normal husband and normal wife (control); $\mathrm{AA} / \beta$-thal trait, denotes for normal husband and $\beta$-thalassemia trait wife or normal wife and $\beta$-thalassemia trait husband; AS/ $\beta$-thal trait, for sickle cell carrier husband and $\beta$-thalassemia trait wife or vice versa; $\beta$ thal trait $\beta$-thal trait, denotes that both husband and wife are carrier for thalassemia major; AS/S- $\beta$-thal, means one partner is carrier for sickle cell disease and other partner is suffering from sickle cell- $\beta$-thalassemia (having compound disease, i.e. sickle cell and $\beta$ thalassemia); $\beta$-thal trait/S- $\beta$-thal, stands for one partner being carrier for thalassemia major and the other counterpart is sickle cell$\beta$-thalassemia; the genotype AA/S- $\beta$-thal, stands for one partner being normal and the other partner is sickle cell- $\beta$-thalassemia; $\mathrm{AE} / \beta$-thal trait, stands for one partner being carrier of hemoglobin $\mathrm{E}$ disease and the other partner is carrier of thalassemia major; SE/ $\beta$ thal trait, denotes that one partner is carrier of thalassemia major and the other partner is suffering from a compound disease of hemoglobin E and sickle cell trait; $\beta$-thal Disorders ( $\beta$-thalassemia disorders), mean here all the above diagnostic genotypes (pooled together) except the normal controls. A total of 280 couples were referred during the period from March 2010 to February 2013. Out of 280 couples, 200 were found normal and 80 couples had different $\beta$ thalassemia/sickle cell disorders. A total of 992 persons (474 males and 518 females) were investigated for $\beta$-thalassemia/sickle cell disorders including the controls.

Intravenous 2-3 mL blood was taken under aseptical conditions from each individual after taking informed/written consent for screening of hemoglobinopathies. Hematological parameters were studied using an automated Blood Cell Counter (Model-MS 5 9, Melet Schloesing Lab., Cergy-Pontoise Cedex, France). Laboratory investigations were carried out following the standard procedures after cross checking for quality control from time to time. The sickling test was performed using $2 \%$ freshly prepared sodium metabisulphite solution as a reducing agent for the presence or absence of sickle cell hemoglobin. ${ }^{13}$ The routine hemoglobin lysate electrophoresis was carried out on cellulose acetate membrane in Tris-ethylenediaminetetraacetic acid-Borate buffer at $\mathrm{pH} 8.9$ and quantification of $\mathrm{A}_{2}$ fraction of adult hemoglobin was done by elution method. ${ }^{13,14}$ The value more than $3.5 \%$ of $\mathrm{A}_{2}$ fraction of adult hemoglobin was taken as cut off point for determining the $\beta$-thalassemia trait. Those individuals having very high hemoglobin $\mathrm{A}_{2}$ value, i.e. more than $10 \%$ were suspected to have $\mathrm{A}_{2}$ plus hemoglobin $\mathrm{E}$; and the test was confirmed by the investigations of other family members. Estimation of fetal hemoglobin was done according to technique described by Weatherall. ${ }^{14}$

The diagnosis of sickle cell- $\beta$-thalassemia was based on the findings of hemoglobin A, F, $\mathrm{S}$ and $\mathrm{A}_{2}$ on electrophoresis under alkaline $\mathrm{pH}$, elevated $\mathrm{A}_{2}$ levels (>3.5\%). All the doubtful cases were further subjected to hemoglobin variant analysis for detecting any discrepancy (Bio-Rad Diagnostics, Hercules, CA, USA).
Data results obtained were analyzed as per the standard statistical methods by performing a 2_2 contingency chi-square test to compare normal with each patient subgroup for the difference between the two independent proportions and significance, if any, is also indicated. For collected data, calculations were made for reproductive wastage (abortions, stillbirths, neonatal mortality, and infant mortality) in percentages and also per thousand live-births, etc. Results were given to parents for treatment and further clinical management by the concerned referring doctor. All the carrier/affected persons were imparted genetic/marriage counseling.

\section{Results}

Theoretically, it is true that mating of carriers of $\beta$-thalassemia has a $25 \%$ probability of getting affected offspring, but at the same time it is equally true that each conception has the same probability (25\%) of getting a normal or affected offspring with $50 \%$ risk of having carrier offspring (as expected), regardless of the previous pregnancy, if any. This independence segregation (dispersal) of defective genes at each conception interferes with the expected outcome of getting a normal, carrier or affected offspring and leads to imbalance of progeny in terms of abortions and still-births and normal, carrier or affected in the family. Results of this study illustrate the actual and factual imbalances of progeny in the vulnerable couples.

The number of conceptions per couple was recorded to be higher in almost all different $\beta$ thalassemia disorders $[\beta$-thal trait $/ \beta$-thal trait (2.457); AA/ $\beta$-thal trait (1.647), AS/ $\beta$-thal trait (3.333); AS/S- $\beta$-thal $(2.250) ; \beta$-thal trait $/ \mathrm{S}-\beta$ thal (2.250); and $\beta$-thalassemia disorders (pooled) (2.475)] than in normal controls (1.480). Carrier couples of thalassemia major (Table 1) had more abortions (4.6\%) and less number of still-births (1.2\%) than in the controls ( $4 \%$ and $3.7 \%$, respectively). Couples of $\beta$ thal trait/S- $\beta$-thal genotypes had the statistically significantly $(\mathrm{P}<0.01)$ lowest live-births (66.7\%) and statistically highly significantly $(\mathrm{P}<0.001)$ highest still-births $(33.3 \%)$ than the controls (91.9\% and $3.7 \%$, respectively). However, the couples of $\mathrm{AA} / \beta$-thal trait genotype although showed higher number of stillbirths (10.7\%) than the controls (3.7\%), yet the difference was not statistically $(<0.10$ $\mathrm{P}>0.05$ ) significant (Table 1).

There was statistically significantly $(\mathrm{P}<0.05)$ higher frequency of neonatal deaths in couples of $\mathrm{AS} / \mathrm{S}$ - $\beta$-thal genotypes (11.1\%); and still higher $(\mathrm{P}<0.001)$ in $\mathrm{AA} / \beta$-thal trait genotypes (14.3\%) as compared to controls (1.3\%). However, the difference between the couples of $\beta$-thalassemia disorders as a whole 
(4.0\%) and controls (1.3\%) was statistically not significant $(<0.10 \quad \mathrm{P}>0.05)$ for neonatal deaths (Table 1).

Just like neonatal deaths, both the couples of $\mathrm{AS} / \mathrm{S}$ - $\beta$-thal $(11.1 \%)$ genotypes $(\mathrm{P}<0.05)$; and $\mathrm{AA} / \beta$-thal trait (14.3\%) genotypes $(\mathrm{P}<0.001)$ showed the higher frequency of infant mortality (i.e. deaths below 1 year) as compared to controls (1.3\%). The difference between the couples of $\beta$-thalassemia disorders as a whole (5.0\%) and controls (1.3\%) was statistically significant $(<0.02)$ for infant deaths (Table 1).

The mortality below 10 years was observed to be higher in almost all the couples of $\beta$-thalassemia disorders (Table 1), specifically significantly higher in couples of $\mathrm{AA} / \beta$-thal trait $(17.8 \%)$ genotypes $(\mathrm{P}<0.001)$ and $\beta$-thalassemia disorders $(8.1 \%)$ as a whole $(\mathrm{P}<0.01)$ than in normal controls $(2.7 \%)$.
However, the carrier couples of $\beta$-thalassemia major (7.0\%), and AS/ $\beta$-thal trait (8.0\%) couples showed statistically insignificantly $(<0.10 \mathrm{P}>0.05)$ higher mortality below 10 years than the controls (2.7\%).

The surviving offspring (Table 1) was statistically significantly lower in couples of $\mathrm{AA} / \beta$ thal trait $(71.4 \% ; \mathrm{P}<0.01)$ and $\beta$-thal trait $/ \mathrm{S}-\beta$ thal $(66.7 \% ; \mathrm{P}<0.05)$ genotypes than in controls (89.2\%).

The conventional system of accurate and precise proportional evaluation of abortions and still-births, and neonatal, infant and childhood mortality is the calculation of 1000 livebirths. The number of abortions per 1000 livebirths was almost same in both carrier of thalassemia major (49.4) and control (44.1) couples (Table 2). However, the frequency of abortions in couples of $\beta$-thalassemia disorders as a whole was low (27.1). The frequency of still- births in carrier couples of thalassemia major (12.3) was almost three times lower than in controls (40.4) per 1000 live-births.

Neonatal and infant mortality per 1000 livebirths were almost doubled in carriers of thalassemia major (24.7 and 37.0, respectively) than in controls (14.7). However, neonatal and infant mortality per 1000 live-births were much higher in couples of $\mathrm{AA} / \beta$-thal trait (160.0, respectively) and AS/S- $\beta$-thal (125.0, respectively) genotypes (Table 2 ) than in controls (14.7).

Below 10 years mortality per 1000 live-births (Table 2) was more than two-folds higher in carriers of thalassemia major (74.1) and almost three times higher in couples of $\beta$-thalassemia disorders as a whole (86.9) than in controls (29.4). The mortality below 10 years per 1000 live-births was many folds higher in couples of AA $/ \beta$-thal trait (200.0), AS/S- $\beta$-thal

Table 1. Comparison of reproductive history of carrier couples with and without different $\beta$-thalassemia disorders.

\begin{tabular}{|c|c|c|c|c|c|c|c|c|c|}
\hline $\begin{array}{l}\text { Genotypes of couples } \\
\text { (diagnosis) }\end{array}$ & Vo. of couples & $\begin{array}{l}\text { No. of } \\
\text { nceptions }\end{array}$ & $\begin{array}{l}\text { Livebirths } \\
\text { (n; \%) }\end{array}$ & $\begin{array}{l}\text { No. of } \\
\text { abortions } \\
(\mathrm{n} ; \%)\end{array}$ & $\begin{array}{l}\text { No. of } \\
\text { stillbirths } \\
(\mathrm{n} ; \%)\end{array}$ & $\begin{array}{c}\text { Neo-natal } \\
\text { deaths* } \\
(n ; \%)\end{array}$ & $\begin{array}{l}<1 \text { year } \\
\text { death }^{\circ} \\
(n ; \%)\end{array}$ & $\begin{array}{c}<10 \text { years } \\
\text { deaths } \\
(n ; \%)\end{array}$ & $\begin{array}{l}\text { Surviving } \\
\text { offspring } \\
\text { (n; \%) }\end{array}$ \\
\hline$\beta$-thal T/ $\beta$-thal T & 35 & 86 & $81 ; 94.2$ & $4 ; 4.6$ & $1 ; 1.2$ & $2 ; 2.3$ & $3 ; 3.5$ & $6 ; 7.0$ & $75 ; 87.2$ \\
\hline $\mathrm{AA} / \beta$-thal T & 17 & 28 & $25 ; 89.3$ & $0 ; 0.0$ & $3 ; 10.7$ & $4 ; 14.3^{\mathrm{d}}$ & $4 ; 14.3^{\mathrm{d}}$ & $5 ; 17.8^{\mathrm{d}}$ & $20 ; 71.4^{\mathrm{c}}$ \\
\hline AS/ $\beta$-thal T & 15 & 50 & $49 ; 98.0$ & $1 ; 2.0$ & $0 ; 0.0$ & $1 ; 2.0$ & $2 ; 4.0$ & $4 ; 8.0$ & $45 ; 90.0$ \\
\hline AS/S- $\beta$-thal & 4 & 9 & $8 ; 88.9$ & $0 ; 0.0$ & $1 ; 11.1$ & $1 ; 11.1^{\mathrm{a}}$ & $1 ; 11.1^{\mathrm{a}}$ & $1 ; 11.1$ & $7 ; 77.8$ \\
\hline$\beta$-thal T/S- $\beta$-thal & 4 & 9 & $6 ; 66.7^{c}$ & $0 ; 0.0$ & $3 ; 33.3^{\mathrm{d}}$ & $0 ; 0.0$ & $0 ; 0.0$ & $0 ; 0.0$ & $6 ; 66.7^{\mathrm{a}}$ \\
\hline $\mathrm{AA} / \mathrm{S}-\beta$-thal & 3 & 4 & $4 ; 100.0$ & $0 ; 0.0$ & $0 ; 0.0$ & $0 ; 0.0$ & $0 ; 0.0$ & $0 ; 0.0$ & $4 ; 100.0$ \\
\hline $\mathrm{AE} / \beta$-thal T & 1 & 7 & $7 ; 100.0$ & $0 ; 0.0$ & $0 ; 0.0$ & $0 ; 0.0$ & $0 ; 0.0$ & $0 ; 0.0$ & $7 ; 100.0$ \\
\hline SE/ $\beta$-thal T & 1 & 4 & $4 ; 100.0$ & $0 ; 0.0$ & $0 ; 0.0$ & $0 ; 0.0$ & $0 ; 0.0$ & $0 ; 0.0$ & $4 ; 100.0$ \\
\hline$\beta$-thal disorders (pooled above all) & 80 & 198 & $184 ; 92.9$ & $5 ; 2.5$ & $8 ; 4.0$ & $8 ; 4.0$ & $10 ; 5.0^{\mathrm{b}}$ & $16 ; 8.1^{c}$ & $168 ; 84.8$ \\
\hline AAAA (normal) & 200 & 296 & $272 ; 91.9$ & $12 ; 4.0$ & $11 ; 3.7$ & $4 ; 1.3$ & $4 ; 1.3$ & $8 ; 2.7$ & $264 ; 89.2$ \\
\hline
\end{tabular}

Difference between diagnostic categories and normal controls is statistically significant at: ${ }^{\mathrm{a}}=\mathrm{P}<0.05 ;{ }^{\mathrm{b}}=\mathrm{P}<0.02 ;{ }^{\mathrm{c}}=\mathrm{P}<0.01 ;{ }^{\mathrm{d}}=\mathrm{P}<0.001$.

*Birth to 28 days (neonatal mortality); ${ }^{\circ}$ birth to 365 days or within 1 year (infant mortality).

Table 2. Comparison of reproductive history (figures are 1000 live-births) of carrier couples with and without different $\beta$-thalassemia disorders.

\begin{tabular}{|c|c|c|c|c|c|c|c|c|c|}
\hline $\begin{array}{l}\text { Genotypes of couples } \\
\text { (diagnosis) }\end{array}$ & $\begin{array}{l}\text { No. of } \\
\text { couples }\end{array}$ & $\begin{array}{l}\text { No. of } \\
\text { conception }\end{array}$ & Livebirth & $\begin{array}{l}\text { No. of } \\
\text { abortions }\end{array}$ & $\begin{array}{l}\text { No. of } \\
\text { stillbirths }\end{array}$ & $\begin{array}{l}\text { No. of } \\
\text { neonatal } \\
\text { deaths* }\end{array}$ & $\begin{array}{l}<1 \text { year } \\
\text { death }^{\circ}\end{array}$ & $\begin{array}{l}<10 \text { years } \\
\text { deaths }\end{array}$ & $\begin{array}{l}\text { Surviving } \\
\text { offspring }\end{array}$ \\
\hline$\beta$-thal T/ $\beta$-thal T & 35 & 86 & 81 & 49.4 & 12.3 & 24.7 & 37.0 & 74.1 & 925.9 \\
\hline $\mathrm{AA} / \beta$-thal T & 17 & 28 & 25 & 0.0 & 120.0 & 160.0 & 160.0 & 200.0 & 800.0 \\
\hline AS/ $\beta$-thal T & 15 & 50 & 49 & 20.4 & 0.0 & 20.4 & 40.8 & 81.6 & 918.4 \\
\hline AS/S- $\beta$-thal & 4 & 9 & 8 & 0.0 & 125.0 & 125.0 & 125.0 & 125.0 & 875.0 \\
\hline$\beta$-thal T/S- $\beta$-thal & 4 & 9 & 6 & 0.0 & 500.0 & 0.0 & 0.0 & 0.0 & 1000.0 \\
\hline AA/S- $\beta$-thal & 3 & 4 & 4 & 0.0 & 0.0 & 0.0 & 0.0 & 0.0 & 1000.0 \\
\hline $\mathrm{AE} / \beta$-thal T & 1 & 7 & 7 & 0.0 & 0.0 & 0.0 & 0.0 & 0.0 & 1000.0 \\
\hline SE/ $\beta$-thal T & 1 & 4 & 4 & 0.0 & 0.0 & 0.0 & 0.0 & 0.0 & 1000.0 \\
\hline$\beta$-thal disorders & 80 & 198 & 184 & 27.1 & 43.5 & 43.5 & 54.3 & 86.9 & 913.0 \\
\hline AA/AA (normal) & 200 & 296 & 272 & 44.1 & 40.4 & 14.7 & 14.7 & 29.4 & 970.6 \\
\hline
\end{tabular}

*Birth to 28 days (neonatal mortality); ${ }^{\circ}$ birth to 365 days or within 1 year (infant mortality). 
(125.0), and $\mathrm{AS} / \beta$-thal trait (81.6) in comparison to controls (29.4).

\section{Discussion}

The findings of the present study are interesting and revealing many practical aspects of those communities which are genetically susceptible to recessively inherited hemolytic disorders such as $\beta$-thalassemia disorders in Central India (Table 1). The present study strongly supports the contention that hereditary factors in the carrier couples, apart from concomitant non-genetic confounding factors, are responsible for the high fetal wastage in the form of abortions, still-births, neonatal and infant mortality, and mortality below 10 years in India. These disorders are the outcome of nonviable homozygosity due to inbreeding inadvertently taking place in the vulnerable communities of the region. ${ }^{15}$ This is the $1^{\text {st }}$ study carried out taking into consideration these causative aspects of high mortality in the state of Madhya Pradesh, India.

Neonatal mortality was almost doubled in carriers of thalassemia major (24.7) than in controls (14.7) per 1000 live-births in the present study (Table 2). These findings have been supported by the high neonatal mortality rate which was 44 and 33 for Madhya Pradesh and India, respectively for the year 2010. These results are consistent with the similar findings reported from Odisha state in India, where the study ${ }^{8}$ has pointed out that there could be several reasons for raised neonatal mortality such as birth asphyxia, pre-eclamptic toxemia, puerperal sepsis, prematurity, low birth-weight babies, maternal malnutrition, serious malarial or other urino-genital tract infections, diarrhea, immunological incompatibility (such as $\mathrm{ABO}$ and Rhesus blood groups) between mother and fetus (hemolytic disease of the newborn), congenital anomalies or hereditary hemolytic disorders such as glucose-6-phosphate dehydrogenase deficiency, physical injuries during intra-uterine period/delivery, etc. besides other abnormal genetics.

There are very few studies available on the subject of fetal wastage in India. The overall neonatal and infant mortality was recorded for carrier couples of thalassemia major to be 24.7 and 37.0, respectively per 1000 live-births against controls (14.7) in the present study (Table 3). Similarly, the infant mortality rate of 62 was the highest for Madhya Pradesh per 1000 live-births as compared to 47 of India for the year 2011. Further, the findings of the present study for carrier couples of $\beta$-thalassemia major per 1000 live-births are not at variance from that of Odisha with respect to neonatal (24.7) and infant (37.0) mortality in Madhya Pradesh. This consistency of findings shows almost similar pattern of consanguinity or inbreeding in Odisha in the communities possessing recessively inherited genetic characters such as $\beta$-thalassemias ${ }^{16}$ that lead to increased homozygosity of deleterious genes, and subsequently to reproductive wastage, that is, abortions, still-births, neonatal and infant mortality or childhood mortality in Central India.

Women's poor reproductive health in India is affected by a variety of socio-cultural and biological factors. ${ }^{10}$ Underlying poor reproductive health among Indian women is due to their poor overall health status on the one hand, and an inadequate delivery system to cater to the needs of secluded, shy and de-valued women on the other. Thus, efforts to improve women's education, raise enrollment and attendance rates of girls in school and reduce the drop-out rate on the one hand, and enhance income autonomy for women on the other, are fundamental issues in the long run for improvements of women and their family health; no less important are the improvements in quality and breadth of services catering to reproductive health needs of the women in Central India.

Unsafe motherhood is still a reality in much of Central India and particularly in its rural areas. Few women have access to antenatal care, high risk cases go undetected, anemia is acute during pregnancy, deliveries are conducted largely by untrained attendants in unhygienic conditions and knowledge of health and nutrition needs during pregnancy and the post-natal period are poorly disseminated. Disparities in women's access to health care at delivery are apparent. The official programs for maternal and child health cares reach a few pregnant and lactating women. Maternal health activities are unbalanced, focused on immunization, and provisions of iron and folic acid rather than on sustained women care or on the identification and detection of genetic abnormalities that are detrimental to their health and do not provide refer- ral services to high risk pregnancies in rural Central India.

Reproductive health services thus imply the enabling of individuals, both males and females, to decide freely and responsibly, the number, spacing and timing of their children. For this they must have the information and the means to attain the highest standard of sexual and reproductive health. Reproductive care, therefore, includes family welfare counseling, contraceptive information and services; safe delivery and post-natal care; infant, and women's health care; abortion; treatment of reproductive tract infections and sexually transmitted diseases; and counseling on human sexuality, reproductive health and responsible parenthood, which is lacking in Central India.

Looking at the overall scenario of reproductive wastage and survival in different carrier couples of $\beta$-thalassemia disorders, the number of normal (free of any type of thalassemia) children $(66 / 168 ; 39.3 \%)$ born to carrier couples was lower than the afflicted heterozygous and homozygous children (102/168; 60.7\%), indicating the progressive increase of afflicted heterozygous and homozygous offspring in these families (Table 4). This trend shows the lower fitness of the carrier couples or affected families, and consequently of the vulnerable population(s).

Urgently needed is greater insight into underlying risk factors, into why women's reproductive health needs remain unmet. Equally important is the need to structure the reproductive health services to respond to the gynecological and obstetric conditions that women experience, and which take into consideration the social, cultural and economic constraints that women face in expressing these conditions and in accessing these services. What are the leading reproductive morbidities observed in community settings? What are the leading conditions observed for different age groups - those in the reproductive ages, adolescents, women

Table 3. Comparison of neonatal mortality and infant mortality rates of Madhya Pradesh and India.

\begin{tabular}{lcc}
$\begin{array}{l}\text { Genotypes of couples } \\
\text { (diagnosis) }\end{array}$ & $\begin{array}{c}\text { Neonatal deaths* } \\
\text { (neonatal mortality) }\end{array}$ & $\begin{array}{c}<1 \text { year deaths } \\
\text { (infant mortality) }\end{array}$ \\
AA/AA (normal) & 14.7 & 14.7 \\
$\beta$-thal trait/ $\beta$-thal trait & 24.7 & 37.0 \\
\hline $\mathrm{AA} / \beta$-thal trait & 160.0 & 160.0 \\
$\mathrm{AS} / \beta$-thal trait & 20.4 & 40.8 \\
\hline $\mathrm{AS} / \mathrm{S}-\beta$-thal & 125.0 & 125.0 \\
$\beta$-thalassemia disorders (average) & 43.5 & 54.3 \\
\hline Madhya Pradesh $^{\#}$ & $44.0(2010)$ & $62.0(2011)$ \\
India $^{\S}$ & $33.0(2010)$ & $47.0(2011)$
\end{tabular}

*Birth to 28 days (neonatal mortality); ${ }^{\circ}$ birth to 365 days or within 1 year (infant mortality); ${ }^{\sharp}$ neonatal mortality rate, ${ }^{\sharp n e o n a t a l ~ m o r t a l i t y ~ r a t e ; ~}$ sinfant mortality rate, taken from Registrar General of India, Sample Registration System (SRS Bulletin, December 2011). 
Table 4. Comparison of surviving children (figures in absolute numbers) of carrier couples with and without different $\beta$-thalassemia disorders.

\begin{tabular}{|c|c|c|c|c|c|c|c|c|c|c|c|}
\hline $\begin{array}{l}\text { Genotypes } \\
\text { of couples } \\
\text { (diagnosis) }\end{array}$ & $\begin{array}{l}\text { No. of Conceptions } \\
\text { couples }\end{array}$ & Livebirths & $\begin{array}{l}\text { Surviving } \\
\mathrm{T} \mathrm{M} \quad \mathrm{F}\end{array}$ & $\begin{array}{l}\text { Hb AA } \\
\text { M F }\end{array}$ & $\begin{array}{l}\text { HbAS } \\
\text { M F }\end{array}$ & $\begin{array}{l}\text { HbSS } \\
\text { M F }\end{array}$ & $\begin{array}{l}\text { S- } \beta \text { - } \\
\text { Thal } \\
\text { M F }\end{array}$ & $\begin{array}{l}\beta \text {-Thal } \\
\text { Trait } \\
\text { M F }\end{array}$ & $\begin{array}{l}\text { Thal. } \\
\text { Major } \\
\text { M F }\end{array}$ & E- $\beta$-Thal & HbAE \\
\hline
\end{tabular}

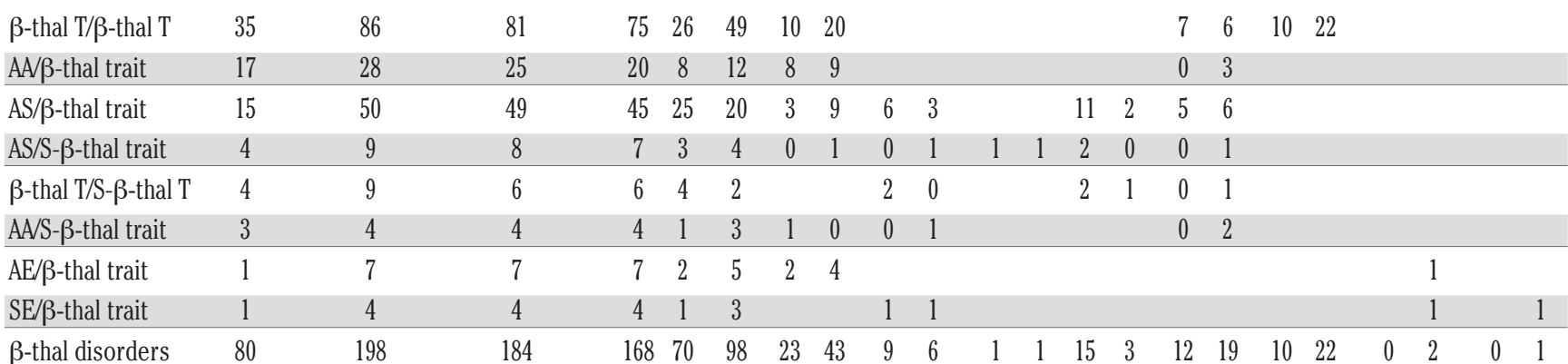
(pooled above all)

AA/AA (normal) $\quad 200 \quad 296 \quad 272 \quad 264124 \quad 140 \quad 124140$

T, total; M, males; F, females. Surviving children: normal offspring=66 (39.3\%); defectives=102 (60.7\%).

beyond the reproductive ages? What are the socio-cultural constraints women face in acquiring good reproductive health and safe pregnancy and delivery? What kinds of interventions can be designed to respond to these needs? Health facilities at the community level are poorly equipped to deal with gynecological emergencies. Therefore, in depth explorations are required especially in Central India.

Thalassemia minor is clinically asymptomatic but some subjects may have moderate anemia. Genetic counseling is recommended and prenatal diagnosis may be offered. ${ }^{17,18}$ Treatment of thalassemia major includes regular RBC transfusions, iron chelation and management of secondary complications of iron overload. In some circumstances, spleen removal may be required. Bone marrow transplantation remains the only definitive cure currently available. Prognosis for individuals of $\beta$-thalassemia has improved substantially during the last 65 years following recent medical advances in transfusion, iron chelation and bone marrow transplantation therapy. ${ }^{9,17,18}$ However, cardiac disease remains the main cause of death in patients with iron overload in Central India.

To bring the reduction/prevention and control of $\beta$-thalassemia disorders/sickle cell disorders in affected families, all the referred and affected families were imparted genetic/marriage counseling to effectively prevent the birth of an abnormal child in their families ${ }^{17,18}$ for the betterment of future generations.

\section{Conclusions}

The increased production of surviving afflicted carrier and diseased offspring (60.7\%) than the normal children (39.3\%), leads to increased morbidity and mortality; and perhaps may be contributing towards increased neonatal/infant mortality in Madhya Pradesh. This is the $1^{\text {st }}$ study that has revealed that hereditary causes also, apart from other concomitant non-genetic factors, are responsible for the high neonatal/infant mortality (reproductive wastage) in the vulnerable population. Further, the progeny of couples with $\beta$-thalassemia disorders contribute disproportionately to the high neonatal/infant mortality in Madhya Pradesh. Affected families were imparted genetic/marriage counseling. It was envisaged to bring awareness among these couples through genetic/marriage counseling about these genetic disorders and their causal effects on health. Their eradication is necessary because they are not curable but preventable through carrier detection, prenatal diagnosis and, education and genetic counseling.

\section{References}

1. Madan N, Sharma S, Sood SK, et al. Frequency of $\beta$-thalassemia trait and other hemoglobinopathies in Northern and Western India. Indian J Hum Genet 2010; 16:16-25.

2. Ambekar SS, Phadke MA, Balpande DN, et al. The prevalence and heterogeneity of beta- thalassemia mutations in the Western Maharashtra population: a hospital based study. Int $\mathrm{J}$ Hum Genet 2001;1:219-23.

3. Varawalla NY, Old JM, Sarkar R, et al. The spectrum of beta-thalassemia mutations in the Indian subcontinent: the basis for prenatal diagnosis. Br J Haematol 1991;78:
242-47.

4. Weatherall DJ, Clegg JB. Inherited haemoglobin disorders: an increasing global health problem. Bull WHO 2001;79:1-15.

5. Balgir RS. Community genetics and health approaches for bringing awareness in tribals for the prevention of beta-thalassemia in India. Thal Rep 2011;1:e2.

6. Weatherall DJ, Clegg JB. The thalassaemia syndromes. 4th ed. Oxford: Blackwell Science Ltd.; 2001. pp 393-349.

7. Nishank SS, Ranjit M, Kar SK, et al. Molecular variants and clinical importance of $\beta$-thalassemia traits found in the state of Orissa, India. Hematology 2009;14:29096.

8. Balgir RS. Infant mortality and reproductive wastage associated with different genotypes of haemoglobinopathies in Orissa, India. Ann Hum Biol 2007;34:1625.

9. Balgir RS. Reproductive wastage in carrier couples of hemoglobinopathies: experiences from a retrospective study in Madhya Pradesh, India. Int J Child Health Hum Develop 2013;6:235-42.

10. Balgir RS. Hematological profile of pregnant women with carrier status of hemoglobin disorders in coastal Odisha, India. Int J Child Health Hum Develop 2011;4:325-32.

11. Balgir RS. Public health challenges of sickle cell disorders, $\beta$-thalassemia syndrome and G6PD deficiency in scheduled caste and scheduled tribe communities of central India. Int Public Health J 2011;3:30718 .

12. Balgir RS. Spectrum of hemoglobinopathies and evaluation of prevalence of beta-thalassemia trait in the tribal land of Middle India. Int Public Health J 
2013;5:165-77.

13. Dacie JV, Lewis SM. Practical hematology. 7th ed. Edinburgh: Churchill Livingstone; 1991. pp 227-258.

14. Weatherall DJ. The thalassemias: methods in hematology. Vol. 6. New York: Churchill Livingstone; 1983. pp 1-53.

15. Balgir RS. Contribution of marital distance to community inbreeding, homozygosis, and reproductive wastage for recessively inherited genetic disorders in Madhya Pradesh, India. Mediterr J Hematol Inf Dis 2013;5:5.

16. Balgir RS. Sickle cell disease and community health issues in Orissa. Indian Pract 1993;46:427-31.

17. Balgir RS. Prevention of hereditary disorders in India: sickle cell disease, $\beta$-tha- lassemia and G6PD deficiency. Bhubaneswar: RMRC (ICMR); 2001. pp 112. [In English and Oriya].

18. Balgir RS. Challenges of imparting IEC for prevention of hereditary sickle cell disorders, $\beta$-thalassemia syndrome and G6PD deficiency in India. Tribal Health Bull 2007;13:14-22. 